\section{World Outlook}

Even a country so widely endowed with resources as the United States has to take cognisance of what is happening elsewhere in a world including rapid population growth, increasing demand and the aspirations of lowincome countries. The world's population is expected to double to 4 billion in the 45-year period to 1975 . The problena of transition would be reduced if there were a sharp reduction in birth-rates; such a step would assist in capital formation-an accumulation which is required not only for tools and transport but also for health and education. More help is required from the industrialized countrios particularly in the next couple of docades.

The general prospect was regarded as a direct challenge to the scientific and technical communities of the United States to help in the development of techniques by which the world can feed itself, ration its water, develop energy and more effectivoly produce more minerals where the richer ores are being depleted. It was essential to understand motives and aspirations; to learn how to communicate effectively; to formulato theorios and programmes of economic development useful to nations of varying resources to population ratios; to work out short-cut mothods in data-collection and planning adapted to the specific needs of emerging economies; to train scientists and technicians for fruitful omployment in their own lands. This knowledge, at present not availablo, would enable the potential assistance of developed countries to be better adapted to the needs of the undeveloped countries.

One of the most urgent problems is how to combine and utilize knowledge of the physical, biological and social processes associated with rosources to enhance produc. tivity and extend flexibility of decision among alternative courses of action. It was necessary "to acquire competence in considering and planning for resource use in complox systems rather than considering only restricted segments of production or use for a single resource".
Certain courses of action are identified, and these the Committee believes should be the basis of a national programme of resources research. The essential details are to be found in the series of individual reports, whioh together with the Summary Report comprised the first report of the Committeo on Natural Resources to the Presidont. The eleven recommendations have the following sub-heads: (1) Extond Applied Research to Adapt Existing Knowledge to Increase Productivity in a Wider Range of Agricultural Environments; (2) Conduct Basic Research in Plant and Animal Genetios and Breeding; (3) Support Research and Related Investigations Leading to Low-cost Sources of Industrial Energy; (4) Increase Support of Hydrologic Research; (5) Develop Comprehonsive Analytical Techniques for the Planning and Management of Water Resources; (6) Reinforce and Extend Foreign Mineral Analyses and Development Aid; (7) Increase Support for Research Relating to tho Discovery and Devolopment of Mineral Deposits; (8) Conduct Research on Pollution and its Effects; (9) Support Ocean Fishories Roseareh; (10) Develop Systems-Analysis Capability for Rosource Planning and Management; (11) Establish a Central Natural Resources Group within the Fedoral Government.

The concluding paragraph of the Summary Report makes the following plea:

"In adapting their research programmes and activitios to the requirements of the problems outlined in this report, governmental and non-governmontal agencies and institutions should take full advantage of the resources of the universities, contracting out especially those studies for which the univorsities aro uniquely equipped. It should be remembered that an important by-product of university research is the training that accompanies it, and the Committeo re-emphasizes the need for training research workers to deal effectively with the problems relating to natural resources. These problems require closer co-operation between natural and social sciontists."

\title{
OBITUARIES
}

\section{Dr. Kenneth Bailey, F.R.S.}

DR. KeNNETH BAILEY, whose work contributod so greatly to our understanding of the structure of muscle and other proteins, died in Cambridge on May 22.

Born in Staffordshire in 1909, Bailey took his B.Sc. and Ph.D. degrees in the Department of Industrial Fermontation of the University of Birmingham under the direction of Prof. F. W. Norris, the subject of his thosis being plant mucilages and enzyme kinetics. The award of $a$ Beit fellowship took him to the Department of Biochemistry in the Imperial College of Scienco and Tochnology, London, where Prof. A. C. Chibnall and his colleagues were investigating tho chomical structure of proteins. There Bailey examined the preparation of protoins from various species of muscle, and under the influence of Prof. W. T. Astbury, a frequent visitor to the Department at that time, he became interested in the behaviour of fibrous proteins in general. This became his principal interest and remained so for the rest of his life, as did his friendship and scientific association with Astbury.

His early papers on such topies as the mechanism of denaturation of globular protoins, the chemicol composition of myosin und tho relation of adenosine triphosphatase to myosin, showed a romarkable undorstanding of the physical, chemical and biological facets of protein structure. Very fow of his contemporaries were able to aequiro so broad on grasp of tho fiold. In 1939 a Rockefeller travelling fellowship enabled him to work in tho laboratory of Prof. E. J. Cohn at Harvard University, but soon after the outbreak of war Bailey roturned to Great Britain and worked for a time at the Low Temperature Research Station at Cambridge, moving later to the Biochemical Laboratory of the University, whore he remained. After war-time work with a group investigating the biochomical effects of organophosphorous compounds, he returned to muscle biochemistry and very soon reported the isolation and crystallization of tropomyosin, a structural protein tho biological function of which remains uncertain but the unusual propertios of which have made it an object of investigation in many laboratories. About this time he began work on the structural relationship of fibrinogen and fibrin, and he continuod to make novel contributions with outstanding skill in these two parallel fields. A papor published less than a year ago described a clean and simple soparation of the peptide chains of fibrin. He was appointed assistant director of resoarch in the Dopartmont of Biochemistry at Cambridge and later became reader. He was olocted a Fellow of the Royal Society in 1953.

Intorest in the electrical tissue of fish took Bailey to the Starione Zoologicn at Naples in 1938, where he made many friends. He returned to Naples at tho first opportunity after tho War and became a regular visitor to that laboratory, where he investigated the muscle proteins of vortebrate and invertebrate fish.

Simplicity was perhaps the outstanding feature of Bailey's experimontal work. He rarely used technical assistance or at any time had more than one research student, and much of his success was due, in his own 
phrase, to his "sympathetic treatment" of proteins during extraction and manipulation. His work in the laboratory was dominated by an awareness that proteins are an integral part of living tissue. $\mathrm{He}$ had great intellectual capacity but also a deep intuitive understanding of both things and people.

Bailey's unusual combination of gifts included an ability to write in a clear and attractive style. Vivid phrases recurred and gave his articles a freshness not often found in scientific literature. Once, in reviewing a rather speculative book, he wrote characteristically of the difficulty in "separating the gems of fact from the trinkets of fancy". He was co-editor of The Proteins, a past member of the Editorial Board of the Biochemical Journal and a joint editor of Advances in Protein Chemistry. Many have reason to be grateful for his ability and patience in changing a turgid typescript into a comprehensible paper. Not surprisingly, these same qualities made him an excellent teacher both in the Biochemistry Department and in Trinity College of which he was elected a Fellow in 1948.

The past ten years of Bailey's life were marred by severe, recurrent illness, but the intervening periods were mercifully long and he was able to continue his fruitful work and retain his creative interest in music, sculpture, poetry and painting. Bailey was a kind, sensitive and gentle person who will be remembered with gratitude and deep affection by his many friends throughout the world.

\section{R. R. Porter}

\section{Prof. C. H. Lobban}

Prof. Charles H. Lobban, who held the chair of civil engineering in King's College, University of London, from 1935 until his retirement in 1946, died on July 13, at the age of eighty-two.

Lobban studied civil engineering at the University of Glasgow and then trained, by pupilage, as a professional engineer. His subsequent career was interesting because it was devoted initially to university teaching, then to professional practice and then to both activities pursued simultaneously. $\mathrm{He}$ served first as demonstrator and lecturer in his own University of Glasgow during 190406, as lecturer at Manchester during 1906-08 and as professor at Madras during 1908-10. He then entered a consulting engineering practice in Kilmarnock and so continued until he was caught up, like most of his generation, in the maelstrom of the First World War. He saw three and a half years of active service in France as a major in the Royal Engineers and was mostly concerned with logistics and vital railway installations. I recall his vivid description of the drama when the 'secret weapon' of the War, the tank, was first brought to the Front. He was wounded in action, but with him this was never a cause for vainglory.

In 1920 his career again took one of its changes in direction when he was appointed lecturer in eivil engineering in King's College, London, becoming senior lecturer in 1923 and reader in 1926 . This was a most fruitful period of his life because he found it possible to combine his teaching of civil engineering with the practice of it. During this time he was responsible for the engineering design of some notable London buildings including Victoria House and the School of Hygiene and Tropical Medicine. He also had charge of some university buildings at Nottingham and elsewhere. In 1935 he succeeded Prof. A. H. Jameson in the chair of civil engineering at King's College, in which appointment he remained until his retirement in 1946. His period of tenure of the chair at King's College was difficult. $\mathrm{He}$ had but a brief time to develop his Department before the outbreak of the Second World War when the College was evacuated to Bristol. There he continued to keep a team together amidst many anxieties, and, equally difficult, to face and organize their return to the war-damaged and dilapidated buildings in the Strand, shortly before he retired.

Lobban's interests were mainly centered on the structural aspects of civil engineering both in his practice, in teaching and in research. He was not a voluminous writer, but was the author of a number of papers dealing with aspects of structural theory. In particular, he was interested in the analysis of structural frames by applying known deformations to a model whereby the stresses in the full-sized structure could be determined. The procedure originated in the United States, but Lobban was one of the first to develop it in Great Britain. In 1924 he was awarded the D.Sc. of the University of Glasgow for a thesis entitled "Grillage and Reinforced Concrete Foundations", a subject in which he was much involved as the engineer for heavy buildings founded on London Clay. Other writings were concerned with the deflexions of structures and the bending of girders when encased in concrete. He also served for a time as technical officer to the Steel Structures Research Committee of the Department of Scientific and Industrial Research.

Lobban had a gift for economy both in the use of words and in the kind of calculations which a civil engineer must undertake. This quality was most evident in his methods of structural analysis; for problems in this field he could usually produce elegant short methods not to be found in the text-books. He was a devoted and most effective teacher whose lectures carried the conviction and inspiration of one who was teaching what he practised. Students not only recognized his authoritative standing in his profession but also admired him as a man, and he enjoyed an enviable popularity with them. A keen golfer, he was captain of Hampstead Golf Club in 1936 and after his retirement became a keen curler. He also delighted in yachting, usually off the west coast of his beloved Scotland, and groups of students generally formed his eager, willing crew. Prof. Lobban will be remembered with respect and affection by generations of his former students.

A. D. Ross

\section{Prof. J. Satterly}

THE death on October 1 of Prof. John Satterly at the age of eighty-three has severed one of the few remaining ties between Canada and the Cavendish Laboratory of J. J. Thomson's days at the beginning of the century. He brought to the University of Toronto an enthusiasm for physics and the delights of experimental investigation which he retained even after he retired from active teaching in 1950.

In his lectures to the first-year students in the honours course in mathematics and physics, which was attended also by students intending to pursue advanced study of biology, he was a vigorous successful teacher. He is remembered by generations of former students, including men and women who are now teachers on the staff of the University, for the training they received from him to be scrupulous and observant. Among American teachers of physics, his papers on the physics of simple phenomena which can be observed even in the kitchen are very well known. He was not an atomic physicist, but, in my own opinion, Satterly's spirit of modest investigation is sadly missing in much of the research and teaching of physics to-day.

Satterly was a Devon man with a deep knowledge of its history. He loved England and was full of historical anecdotes of British science. $\mathrm{He}$ was a close personal friend of Dr. Searle - a link with Clerk Maxwell.

In the Royal Society of Canada to which he was elected in 1917, he was a genial member, and he was well known as a popular lecturer in Toronto, for he showed a fine spirit of fun on these occasions. His achievement is shown in the lives of those who were influenced by him.

W. H. Watson 